\title{
Effects of chromium picolinate on fat deposition, activity and genetic expression of lipid metabolism-related enzymes in 21 day old Ross broilers
}

\author{
Guangxin Chen ${ }^{1,2,3, a}$, Zhenhua Gao ${ }^{3, a}$, Wenhui Chu ${ }^{1,2}$, Zan $\mathrm{Cao}^{3}$, Chunyi $\mathrm{Li}^{1,2}$, and Haiping Zhao ${ }^{1,2, *}$
}

\author{
* Corresponding Author: Haiping Zhao \\ Tel: +86-18143102126, Fax: +86-0431-81919800, \\ E-mail: zhperic@163.com \\ ${ }^{1}$ State Key Laboratory of Special Animal Molecular \\ Biology, Changchun 130112, China \\ 2 Institute of Special Animal and Plant Sciences \\ of Chinese Academy of Agricultural Sciences, \\ Changchun 130112, China \\ ${ }^{3}$ College of Agriculture, Guangdong Ocean University, \\ Zhanjiang 524000, China \\ a Guangxin Chen and Zhenhua Gao contributed to the \\ paper equally. \\ ORCID \\ Haiping Zhao \\ https://orcid.org/0000-0001-7367-3490
}

Submitted Apr 15, 2017; Revised Jun 5, 2017; Accepted Aug 21, 2017
Objective: This experiment was conducted to investigate the effects of chromium picolinate (CrP) on fat deposition, genetic expression and enzymatic activity of lipid metabolism-related enzymes.

Methods: Two hundred forty one-day-old Ross broilers were randomly divided into 5 groups with 4 replicates per group and 12 Ross broiler chicks per replicate. The normal control group was fed a basal diet, and the other groups fed the same basal diet supplemented with $0.1,0.2$, 0.4 , and $0.8 \mathrm{mg} / \mathrm{kg} \mathrm{CrP}$ respectively. The experiment lasted for 21 days.

Results: Added CrP in the basal diet decreased the abdominal fat, had no effects on subcutaneous fat thickness and inter-muscular fat width; $0.2 \mathrm{mg} / \mathrm{kg} \mathrm{CrP}$ significantly decreased the fatty acid synthase (FAS) enzymatic ( $p<0.05)$; acetyl-CoA carboxylase (ACC) enzymatic activity decreased in all CrP groups $(\mathrm{p}<0.05)$; hormone-sensitive lipase (HSL) enzymatic activity also decreased, but the change was not significant ( $>0.05$ ); $0.4 \mathrm{mg} / \mathrm{kg} \mathrm{CrP}$ group significantly decreased the lipoprotein lipase (LPL) enzymatic activity. FAS mRNA expression increased in all experimental groups, and the LPL mRNA expression significantly increased in all experimental groups ( $\mathrm{p}<0.05)$, but not $0.2 \mathrm{mg} / \mathrm{kg} \mathrm{CrP}$ group.

Conclusion: The results indicated that adding $\mathrm{CrP}$ in basal diet decreased the abdominal fat percentage, had no effects on subcutaneous fat thickness and inter-muscular fat width, decreased the enzymatic activity of FAS, ACC, LPL and HSL and increased the genetic expression levels of FAS and LPL.

Keywords: Ross Broiler; Chromium Picolinate (CrP); Fatty Acid Synthase; Acetyl-CoA Carboxylase; Hormone-sensitive Lipase; Lipoprotein Lipase; Enzymatic Activity; mRNA Expression

\section{INTRODUCTION}

Chromium (Cr) exists in various oxidation states $(-2$ to +6$)[1],+3$ and +6 are the most naturally states in environment [2]. Hexavalent $\mathrm{Cr}$ is more toxic than trivalent [3-5] when measured for genotoxicity, cytotoxicity, and carcinogenicity [6-8]. Trivalent $\mathrm{Cr}$ is the most stable form, and have less toxicity. So the Hexavalent $\mathrm{Cr}$ is usually used for toxicologic study, and the trivalent $\mathrm{Cr}$ is usually used as a nutrient element. Chromium is an integral component of the glucose tolerance factor [9]. The low molecular weight chromium binding substance was known as chromodulin, is the most viable candidate for the biologically active form of $\mathrm{Cr}^{3+}$ which could stimulate the activity of the insulin receptor protein tyrosine kinase [10]. Chromodulin and its synthetic analogue increase the activity of tyrosine kinase 3 to 8 fold [11].

Previous studies indicated that organic $\mathrm{Cr}$ is absorbed more efficiently [12], and has a higher bioavailability than inorganic $\mathrm{Cr}$ [13]. Different organic forms of $\mathrm{Cr}$ would be ex- 
pected to have different bioavailabilities $[12,14]$. Published studies describing the effects of organic $\mathrm{Cr}$ on broilers, including increasing immune response and alleviating the negative effects of heat stress $[15,16]$, increasing the weight of pectoral muscles [17], decreasing body fat deposition in broilers [18]. In addition, supplement with $\mathrm{Cr}$ alter lipid and glucose metabolism [19-21], and growth performance in pigs [22]. Cr improved glucose tolerance [23,24], decreased total cholesterol and low-density lipoprotein levels $[25,26]$. The previous studies indicated that $\mathrm{Cr}$ alter lipid and glucose metabolism, but the underlying mechanism is unknown.

Therefore, this study was conducted to investigate the effects of chromium picolinate (CrP) on percentages of abdominal, subcutaneous and inter-muscular fat, enzyme activities and mRNA expression in Ross broilers, via adding $\mathrm{CrP}$ in dietary to reveal the mechanism underlying the effects of $\mathrm{Cr}$ on lipid metabolism.

\section{MATERIALS AND METHODS}

Animals, diets, and treatments

A total of 240 one-day-old Ross broilers were randomly divided into 5 groups, and each group containing 4 replicates of 12 Ross broilers. The normal control group was fed the basal diet, the other groups fed the same basal diet supplemented with $0.1,0.2,0.4,0.8 \mathrm{mg} / \mathrm{kg} \mathrm{CrP}$. The experiment lasted for 21 days. $\mathrm{CrP}$ in this experiment was supplied by Shaanxi Pioneer Biotech Co., Ltd. The commodity's CAS No.: 14639-25-9; Model No.: PW-S67, CrP content: 98\%. The corn-soybean meal basal diet was used in this experiment, in accordance with the National Research Council (NRC [27]). Standard for broilers nutrient requirements and Chinese Feeding Standard for broilers. Table 1 lists the composition and nutrient levels of the basal diet. The Cr concentration in basal diets is $0.33 \mathrm{mg} / \mathrm{kg}$, just same as report by Padmavathi [28].

\section{Feeding managements}

All experimental utensils and surroundings were disinfected before initiating the experiment. During the experiment, feed and water were given ad libitum. During days 1 to 3 , the indoor temperature was maintained at $33^{\circ} \mathrm{C}$ to $35^{\circ} \mathrm{C}$ and decreased gradually reach to $24^{\circ} \mathrm{C}$ after 14 days. Natural ventilation and humidity was maintained at $55 \%$ to $60 \%$. During days 1 to 3 , the broilers were exposed to light for 24 hours, and after three days, the broilers were exposed to light for 20 to 23 hours.

\section{Sample collection}

On days 21, the experimental Ross broilers starved for 12 hours, then two Ross broilers were selected from each replicates and killed at the neck. The abdominal fat was subsequently separated and weighed, and the subcutaneous and inter-muscular fat width were measured. Liver and pectoralis were collected
Table 1. Composition of the basal diet

\begin{tabular}{lc}
\hline Items & \\
\hline Ingredient (\%) & \\
Corn & 58.00 \\
Soybean meal & 30.50 \\
Fish meal & 3.50 \\
Soybean oil & 2.50 \\
Wheat bran & 2.00 \\
Shell powder & 1.50 \\
CaHPO & 1.10 \\
NaCl & 0.25 \\
Met & 0.15 \\
Premix & $1)$ \\
Total & 0.50 \\
Nutrient levels & 100.00 \\
ME (MJ/kg) & \\
CP & 12.35 \\
Ca & 20.82 \\
TP & 0.99 \\
AP & 0.67 \\
Lys & 0.44 \\
Met+Cys & 1.15 \\
\hline ME & 0.83
\end{tabular}

$M E$, metabolizable energy; $C P$, crude protein; TP, total phosphorus; AP, available phosphorous.

1) The premix contained in per kilogram of the diet: vitamins $A, 10,000$ IU; vitamins $B_{1}, 1.75 \mathrm{mg}$; vitamins $B_{2}, 4.25 \mathrm{mg}$; vitamins $B_{6}, 3.25 \mathrm{mg}$; vitamins $B_{12}, 0.025 \mathrm{mg}$; vitamins $D_{3}$, 2,500 IU; vitamins $E, 15.00$ mg; vitamins $K_{3}, 1.75$ mg; pantothenic acid, $15.00 \mathrm{mg}$; nicotinic acid, $2.00 \mathrm{mg}$; biotin, $0.30 \mathrm{mg}$; choline, 1,100 mg; folic acid, 0.75 mg; Mn, 86 mg; Zn, 100.00 mg; Fe, 100.00 mg; Cu, 8.00 mg; l, 0.40 $\mathrm{mg}$; Se, $0.20 \mathrm{mg}$.

and placed into liquid nitrogen and then stored at $-80^{\circ} \mathrm{C}$ to be measured (The study protocol conforms to the guide for the use of laboratory animals form the College of Agriculture, Guangdong Ocean University).

\section{Fat deposition, subcutaneous fat thickness, inter-} muscular fat width measurement

Abdominal fat percentage

$=($ Abdominal fat weight $/$ body weight $) \times 100 \%$

Subcutaneous fat thickness: An incision was made at the former end of the caudal vertebra along the middle line of the back. The incised skin corner (including the skin) was measured at different positions with Vernier calipers to obtain three numbers. The averaged number is the subcutaneous fat thickness.

Inter-muscular fat width: The inter-muscular fat width was measured at three different position from the pectoral muscle major border to the sternum end, and the averaged number is the inter-muscular fat width.

Enzymatic activity of FAS, ACC, LPL, and HSL 
Approximately 50 to $100 \mathrm{mg}$ of liver, or pectoralis were placed into tubes. Lysis buffer $(50 \mu \mathrm{M}$ Tris with $50 \mu \mathrm{M} \mathrm{Nal}, \mathrm{pH}$ was adjusted to 7.5 with $\mathrm{HCl}$ ) was added to the tube and the contents were ground down by the cell/tissue crusher. 12,000 g centrifuged for $10 \mathrm{~min}$ at $4^{\circ} \mathrm{C}$. The supernatant was used to measure the enzymatic activity of fatty acid synthase (FAS), acetyl-CoA carboxylase (ACC), hormone-sensitive lipase (HSL), and lipoprotein lipase (LPL) by enzyme-linked immunosorbent assay (ELISA) kits according to the instructions provided by the manufacturer (Shanghai Jiang Lai Biotechnology Co., Ltd, Shanghai, China). Briefly, $50 \mu \mathrm{L}$ supernatant samples was added to the coated plate, incubated at $37^{\circ} \mathrm{C}$ for 1 hour, then washed three times with phosphate-buffered saline (PBS) (each $5 \mathrm{~min}$ ); $50 \mu \mathrm{L}$ diluted enzyme-labeled antibody was added to the plate, incubated at $37^{\circ} \mathrm{C}$ for 1 hour, then washed three times with PBS; $100 \mu \mathrm{L}$ TMB was added and incubated at $37^{\circ} \mathrm{C}$ for $20 \mathrm{~min}$; terminated the reaction with $50 \mu \mathrm{L} 2 \mathrm{M} \mathrm{H}_{2} \mathrm{SO}_{4}$, and measured the optical delnsity (OD) at $450 \mathrm{~nm}$.

RNA extraction, reverse transcription and quantitative real-time polymerase chain reaction analysis

Approximately 50 to $100 \mathrm{mg}$ of liver or fat were placed into RNase-free tubes. Trizol (1 mL) (Ambion, Austin, TX, USA) was added to the tube, ground down the tissues with a cell/ tissue grinder, then added $200 \mu \mathrm{L}$ chloroform, and centrifuged at $12,000 \mathrm{~g}$ for $10 \mathrm{~min}$ at $4^{\circ} \mathrm{C}$; transferred the supernatant into a new RNase-free tube, and added $500 \mu \mathrm{L}$ isopropanol, then centrifuged at $12,000 \mathrm{~g}$ for $10 \mathrm{~min}$ at $4^{\circ} \mathrm{C}$; removed the supernatant, washed the precipitate two times with $1 \mathrm{~mL} 75 \%$ ethyl alcohol and centrifuged at $12,000 \mathrm{~g}$ for $10 \mathrm{~min}$ at $4^{\circ} \mathrm{C}$; resuspended the precipitate with DEPC water. Quantified the concentration by measuring the absorbance at 260 and 280 $\mathrm{nm}$. The RNA was subjected to a quantitative real-time polymerase chain reaction (qRT-PCR) using the PrimeScript II 1 st strand cDNA Synthesis Kit (Takara Bio, Dalian, China). The expression levels of FAS and LPL were evaluated by qRT-PCR analysis using the Fast Start Universal SYBR Green Master kit (Roche, Basel, Switzerland). The reaction system was as follows: $12.5 \mu \mathrm{L}$ FastStart Universal SYBR Green Master (ROX), $1 \mu \mathrm{L}$ cDNA, $1 \mu \mathrm{L}$ upstream primer, $1 \mu \mathrm{L}$ downstream primer, and $9.5 \mu \mathrm{L}$ ddH2O. Reaction conditions: $50^{\circ} \mathrm{C}$ for $2 \mathrm{~min}$ followed by 40 cycles at $95^{\circ} \mathrm{C}$ for $10 \mathrm{~min}, 95^{\circ} \mathrm{C}$ for $15 \mathrm{~s}$ and $60^{\circ} \mathrm{C}$ for $1 \mathrm{~min}$. Each sample consisted of three replicates and three internal references. The sequences of FAS, LPL, and glyceraldehyde-3-phosphate dehydrogenase of broilers were obtained from the GenBank. Primer 5 was used to design the primers (Table 2), and synthesized by Sangon Biotech (Shanghai, China) Co., Ltd.

\section{Statistical analysis}

Results were expressed as means \pm standard error. Data were analyzed by using statistical software package SPSS 12.0 (SPSS
Table 2. The primer sequences of FAS, LPL, and GAPDH

\begin{tabular}{lllc}
\hline Gene & Sequences $\left(\mathbf{5}^{\prime}\right.$-3') & Accession No. & $\begin{array}{c}\text { Product } \\
\text { bp }\end{array}$ \\
\hline FAS & $\begin{array}{l}\text { CAATGGACTTCATGCCTCGGT } \\
\text { GCTGGGTACTGGAAGACAAACA }\end{array}$ & NM_205155.2 & 119 \\
LPL & $\begin{array}{l}\text { GTGACCAAGGTAGACCAGCC } \\
\text { GAAGAGACTTCAGGCAGCGT }\end{array}$ & NM_205282.1 & 92 \\
GAPDH & ATGGCATCCAAGGAGTGA & XM_010210168.1 & 141 \\
& GGGAGACAGAAGGGAACAG & & \\
\hline
\end{tabular}

$F A S$, fatty acid synthase; LPL, lipoprotein lipase; GAPDH, glyceraldehyde-3-phosphate dehydrogenase.

Inc., Chicago, IL, USA). Groups were compared by one-way analysis of variance followed by the least significant difference test. ${ }^{\star} \mathrm{p}<0.05$ was considered significant, and ${ }^{\star *} \mathrm{p}<0.01$ was considered markedly significant.

\section{RESULTS}

\section{Effects of CrP on fat deposition of Ross broilers} Compared to normal control group, $0.4 \mathrm{mg} / \mathrm{kg}$ CrP group significantly decreased the abdominal fat percentage $(\mathrm{p}<0.05)$, while the rest of the experimental groups only showed a slight reduction $(\mathrm{p}>0.05)$ (Figure 1A). There was no significant change between the experimental and normal control group on the subcutaneous fat width ( $p>0.05$ ) (Figure 1B). The changes in the inter-muscular fat width consistent with the observed in abdominal fat percentage, $0.4 \mathrm{mg} / \mathrm{kg} \mathrm{CrP}$ decreased the most, but there was no significant change ( $>0.05)$ (Figure 1C).

Effects of CrP on the enzymatic activities of FAS, ACC, LPL, and HSL of Ross broilers

As shown in Figure 2, the FAS activity of all experimental groups decreased compared with the normal control group ( $\mathrm{p}>0.05)$, and $0.2 \mathrm{mg} / \mathrm{kg}$ CrP significantly decreased the activity of FAS ( $\mathrm{p}<0.05)$ (Figure 2A). The enzymatic activity of ACC was significantly decreased in all experimental groups $(\mathrm{p}<0.05)$ (Figure 2B). HSL activity was also decreased, but the differences were not significant ( $>0.05$ ) (Figure 2C). Supplementing with $0.4 \mathrm{mg} / \mathrm{kg} \mathrm{CrP}$ significantly decreased the LPL activity compare to normal control group $(\mathrm{p}<0.05)$ (Figure 2D).

\section{Effects of CrP on mRNA expression levels of FAS and}

\section{LPL in Ross Broilers}

Basal diets added with CrP influenced expression levels of FAS and LPL in Ross broilers of 1 to 21 days. Compared to the normal control group, expression levels of FAS increased in all the experimental groups (Figure 3A). LPL expression levels were significantly decreased $(\mathrm{p}<0.05)$ in $0.2 \mathrm{mg} / \mathrm{kg} \mathrm{CrP}$ group, while it increased in the rest of the experimental groups (Figure 3B). 
A

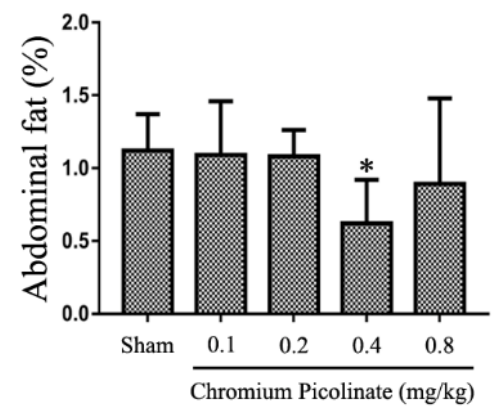

$\mathrm{B}$

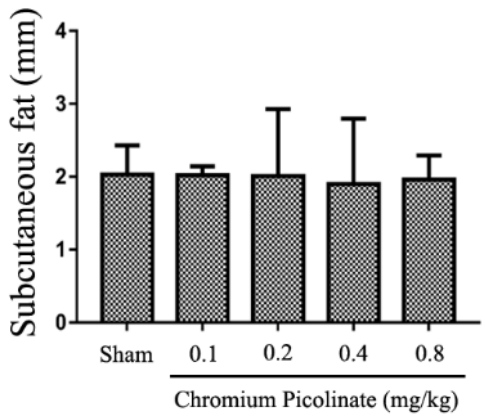

$\mathrm{C}$

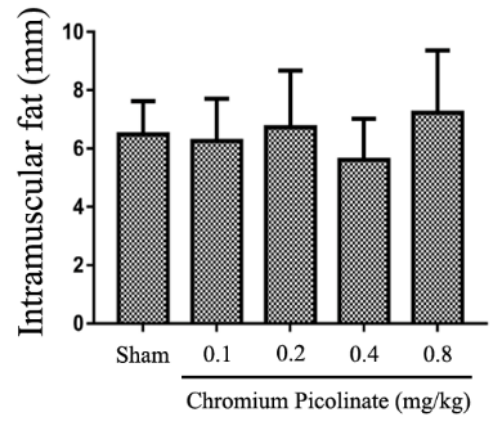

Figure 1. (A) The abdominal fat percentage of Ross broilers, abdominal fat weight/body weight $(n=8)$; (B) an incision was made at the former end of the caudal vertebra along the middle line of the back. The incised skin corner (including the skin) was measured at different positions with Vernier calipers to obtain three numbers. The averaged number is the subcutaneous fat thickness $(n=8) ;(C)$ the inter-muscular fat width was measured at three different position from the pectoral muscle major border to the sternum end, and the averaged number is the inter-muscular fat width $(n=8)$.
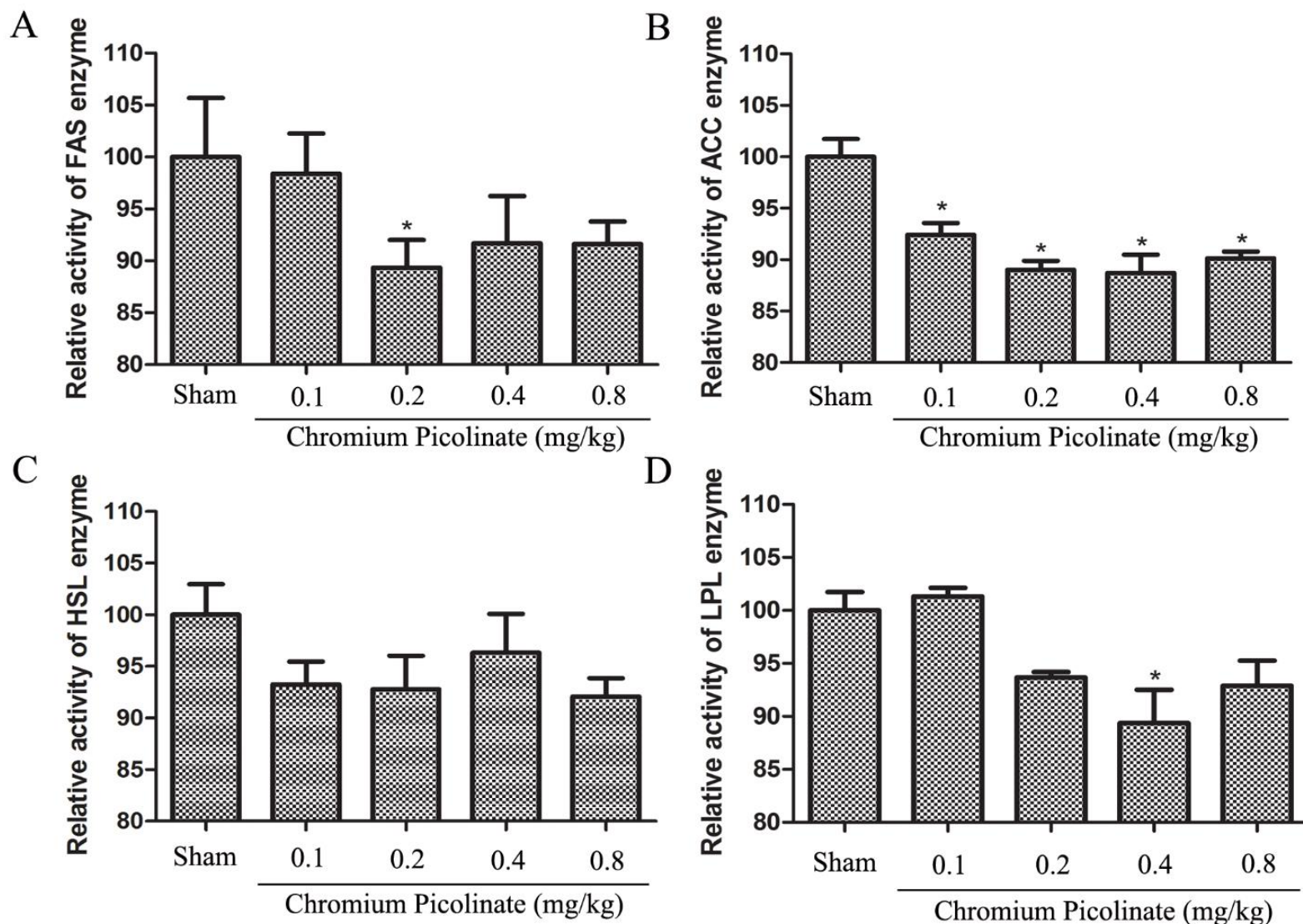

$\mathrm{D}$

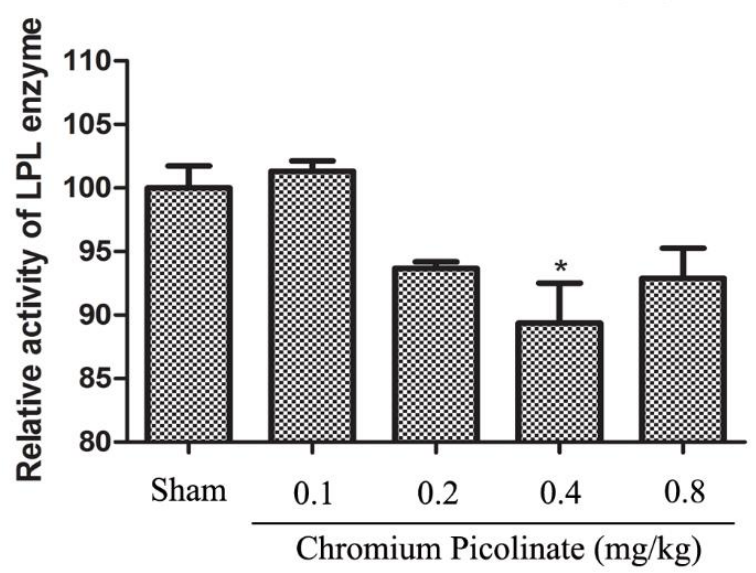

Figure 2. (A), (B), (C), (D) were the relative activity of FAS, ACC, HSL, and LPL enzyme respectively (100\% of control). FAS, fatty acid synthase; ACC, acetyl-CoA carboxylase; HSL, hormone-sensitive lipase; LPL, lipoprotein lipase.

\section{DISCUSSION}

Studies have shown that $\mathrm{Cr}$ can improve glycometabolism and lipid metabolism in diabetes mellitus [29-31], due to its role in glucose/insulin metabolism [32]. Previous studies also indicated that $\mathrm{Cr}$ could affect lipid metabolism and reduce body fat deposition of broilers $[18,28,33]$. Abdominal fat tissue grows faster compared with other fat tissues in poultry [34]. And the abdominal fat is a reliable parameter for judging the total body fat content because it is linked directly to total body fat content in avian species $[35,36]$. Our results showed that abdominal fat percentage tended to be reduced in all experimental groups ( $p>0.05$ ), and the experimental group with 0.4 $\mathrm{mg} / \mathrm{kg} \mathrm{Cr}$ had the most significant reduction $(\mathrm{p}<0.05)$. Basal 

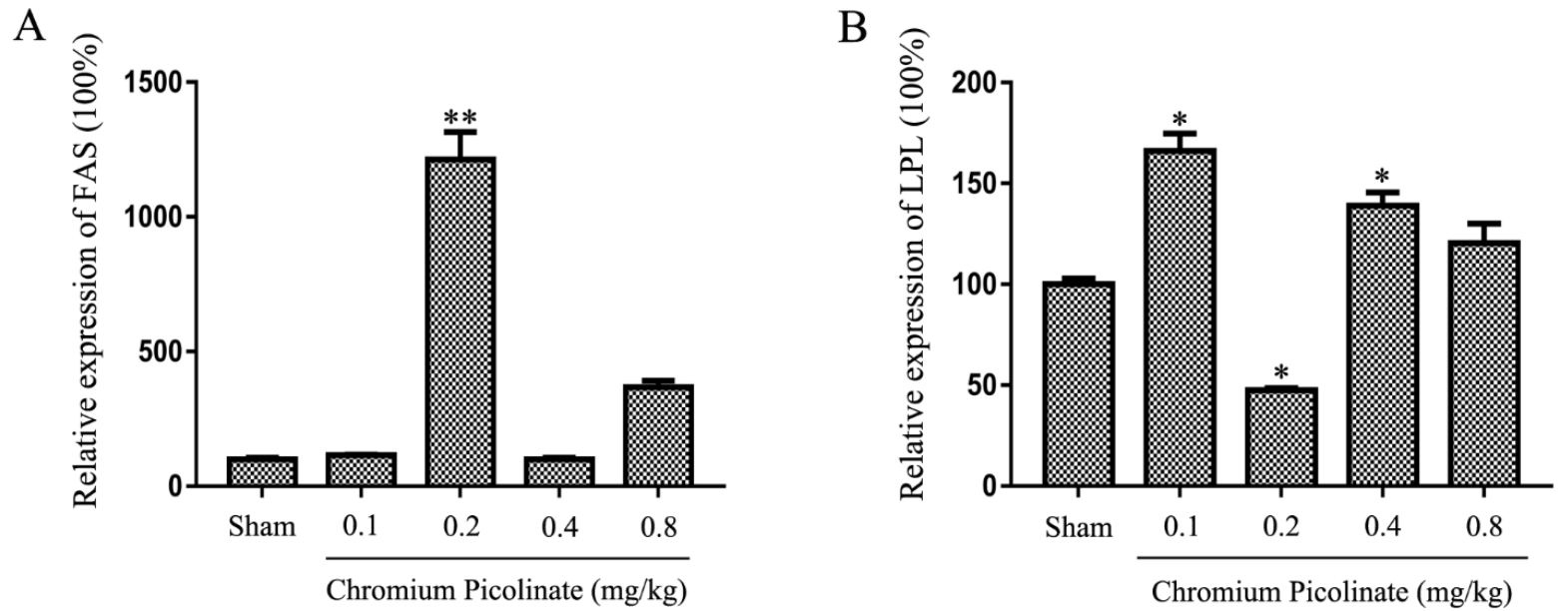

Figure 3. (A) the relative mRNA expression level of FAS; (B) the relative mRNA expression level of LPL (100\% of control). FAS, fatty acid synthase; LPL, lipoprotein lipase.

diets supplemented with $\mathrm{Cr}$ had not effects on the subcutaneous fat thickness and the inter-muscle fat width of Ross broilers.

FAS is the rate-limiting enzyme in the last step of de novo synthesis of the long-chain fatty acids in animals, catalyzes Acetyl-CoA and Maloney-CoA to synthesize the fatty acid [37]. The liver and fat tissue is enriched with FAS, but more than $90 \%$ fatty acid is synthesized in the liver of the broiler, and the fat tissue just has a storage function. Therefore, the experiment reported here used liver to study FAS activity. The results showed that $\mathrm{Cr}$ decreased FAS activity in all experimental groups, and this is consistent with the previous study that clenbuterol decrease lipogenesis in the liver by decreasing FAS activity, consequently affecting the abdominal fat pad weight [38]. The ACC is a biotin-dependent enzyme that catalyzes the carboxylation of acetyl-CoA to produce malonylCoA substrate for the biosynthesis of fatty acids [39]. Due to its unique position in lipid metabolism, inhibition of ACCs has been proposed to reduce lipogenesis and favor lipid oxidation [40]. Our results suggested that the liver ACC activity decreased in all experimental groups, and $0.4 \mathrm{mg} / \mathrm{kg} \mathrm{CrP}$ reduced the most. HSL is controlled by many hormones, so it is also called hormone-sensitive lipase or fat-hormone sensitive enzyme. HSL hydrolyzes fat into non-esterified fatty acids and glycerin by joint function of double-glyceridase and singleglyceridase. However, the hydrolytic activity of HSL is much lower than the other enzymes, making it the rate-limiting enzyme in fat hydrolytic processes [41]. Our study found that HSL activity reduced in all experimental groups ( $p>0.05)$. LPL is a key enzyme of fat deposition in animal tissues. It is a ratelimiting enzyme for the catalysis of triglycerides into glycerin and non-esterified fatty acids [42]. The products of LPL catalysis provide raw material for fat synthesis and play an important role in fat metabolism and transportation. Our results suggested that $\mathrm{CrP}$ tended to decreased the LPL activity in experimen- tal groups, especially for $0.4 \mathrm{mg} / \mathrm{kg}$ group which significantly decreased the LPL activity. All the results showed that supplemented with $\mathrm{CrP}$ in basal diets had certain effects on the enzymatic activity of fat deposition: including reduced FAS activity in the liver, significantly reduced ACC activity in the liver, reduced HSL activity in abdominal fat and reduced the LPL activity in pectorals. Therefore, we thought that $\mathrm{CrP}$ decreased fat deposition through decreasing the enzymatic activities of FAS, ACC, HSL, and LPL. Though HSL activity was also reduced, it was not significant compared to the former.

Supplemented with $\mathrm{CrP}$ in the basal diets significantly decreased the enzyme activity involved in lipid metabolism. Then, whether or not supplemented with CrP would influence the gene involved in lipid metabolism. Our results showed that the expression of FAS significantly increased in $0.2 \mathrm{mg} / \mathrm{kg}$ and $0.8 \mathrm{mg} / \mathrm{kg}$ groups, and the expression of LPL were significantly decreased in $0.2 \mathrm{mg} / \mathrm{kg}$ group ( $\mathrm{p}<0.05$ ), while it significantly increased in $0.1 \mathrm{mg} / \mathrm{kg}$ and $0.4 \mathrm{mg} / \mathrm{kg}$ group $(\mathrm{p}<0.05)$. Though we had not concluded the effects of $\mathrm{Cr}$ on the mRNA expression of FAS and LPL in Ross broilers were correlated with dosage, but we could conclude a series of conclusion when we linked the mRNA expression of FAS and LPL with the enzymatic activity. The regression analysis of FAS activity and FAS gene expression showed that the intercept is 53.80 and the variable is -0.38 (raw data analysis). The regression analysis indicated that the expression of FAS would increase along with the decrease of FAS activity. Therefore, we concluded that supplement Cr could decrease FAS activity, and the low enzymatic activity of FAS in turn stimulate the organism to produce more FAS to meet its needs, lead to the increase of the expression of FAS. However, there was no obvious regularity on the LPL enzyme activity and mRNA expression.

\section{CONCLUSION}


Basal diets with CrP reduced the abdominal fat percentage and subcutaneous fat thickness of Ross broilers of 1 to 21 days, decreased the enzymatic activities of FAS, ACC, LPL, and HSL activity, increased the expression of FAS gene in Ross broilers. And we thought that Cr could decrease FAS activity, and the low enzymatic activity of FAS in turn stimulate the organism to produce more FAS to meet its needs. However, these changes did not appear to be related to the Cr dosage.

\section{CONFLICT OF INTEREST}

We certify that there is no conflict of interest with any financial organization regarding the material discussed in the manuscript.

\section{ACKNOWLEDGMENTS}

We wish to thank our colleagues of Deer Antler Research Group at Chinese Academy of Agricultural Sciences and classmates of Guangdong Ocean University for their contributions to the study. The researches that are involved in this review are funded by State 863 Project (2011AA100603) and "The research and application of feed additives to improve quality of muscles".

\section{REFERENCES}

1. Garcia-Nino WR, Zazueta C, Tapia E, Pedraza-Chaverri J. Curcumin attenuates $\mathrm{Cr}(\mathrm{VI})$-induced ascites and changes in the activity of aconitase and $\mathrm{F}(1) \mathrm{F}(0)$ ATPase and the ATP content in rat liver mitochondria. J Biochem Mol Toxicol 2014; 28:522-7.

2. Chandra AK, Chatterjee A, Ghosh R, Sarkar M, Chaube SK. Chromium induced testicular impairment in relation to adrenocortical activities in adult albino rats. Reprod Toxicol 2007; 24:388-96.

3. Myers JM, Antholine WE, Myers CR. The intracellular redox stress caused by hexavalent chromium is selective for proteins that have key roles in cell survival and thiol redox control. Toxicology 2011;281:37-47.

4. Thompson CM, Gregory Hixon J, Proctor DM, et al. Assessment of genotoxic potential of $\mathrm{Cr}(\mathrm{VI})$ in the mouse duodenum: an in silico comparison with mutagenic and nonmutagenic carcinogens across tissues. Regul Toxicol Pharmacol 2012;64:68-76.

5. Castro MP, de Moraes FR, Fujimoto RY, da Cruz C, Belo MA, de Moraes JR. Acute toxicity by water containing hexavalent or trivalent chromium in native Brazilian fish, Piaractus mesopotamicus: anatomopathological alterations and mortality. Bull Environ Contam Toxicol 2014;92:213-9.

6. Kimura T, Okumura F, Onodera A, Nakanishi T, Itoh N, Isobe M. Chromium (VI) inhibits mouse metallothionein-I gene transcription by modifying the transcription potential of the co-activator p300. J Toxicol Sci 2011;36:173-80.

7. Haney JT, Jr., Erraguntla N, Sielken RL, Jr., Valdez-Flores C. Development of an inhalation unit risk factor for hexavalent chromium. Regul Toxicol Pharmacol 2014;68:201-11.

8. Thompson CM, Kirman CR, Proctor DM, et al. A chronic oral reference dose for hexavalent chromium-induced intestinal cancer. J Appl Toxicol 2014;34:525-36.

9. Schwarz K, Mertz W. Chromium(III) and the glucose tolerance factor. Arch Biochem Biophys 1959;85:292-5.

10. Vincent JB. Relationship between glucose tolerance factor and low-molecular-weight chromium-binding substance. J Nutr 1994;124:117-9.

11. Davis CM, Royer AC, Vincent JB. Synthetic multinuclear chromium assembly activates insulin receptor kinase activity: functional model for low-molecular-weight chromium-binding substance. Inorganic chemistry 1997;36:5316-20.

12. Sadeghi M, Najaf Panah MJ, Bakhtiarizadeh MR, Emami A. Transcription analysis of genes involved in lipid metabolism reveals the role of chromium in reducing body fat in animal models. J Trace Elem Med Biol 2015;32:45-51.

13.Staniek H, Krejpcio Z. The Effects of Supplementary Cr3 (Chromium(III) Propionate Complex) on the Mineral Status in Healthy Female Rats. Biol Trace Elem Res 2017.

14. Emami A, Ganjkhanlou M, Zali A. Effects of Cr methionine on glucose metabolism, plasma metabolites, meat lipid peroxidation, and tissue chromium in Mahabadi goat kids. Biol Trace Elem Res 2015;164:50-7.

15.Ebrahimzadeh SK, Farhoomand P, Noori K. Immune response of broiler chickens fed diets supplemented with different level of chromium methionine under heat stress conditions. AsianAustralas J Anim Sci 2012;25:256-60.

16. Ghazi S, Habibian M, Moeini MM, Abdolmohammadi AR. Effects of different levels of organic and inorganic chromium on growth performance and immunocompetence of broilers under heat stress. Biol Trace Elem Res 2012;146:309-17.

17.Debski B, Zalewski W, Gralak MA, Kosla T. Chromium-yeast supplementation of chicken broilers in an industrial farming system. J Trace Elem Med Biol 2004;18:47-51.

18. Arvizu RR, Dominguez IA, Rubio MS, et al. Effects of genotype, level of supplementation, and organic chromium on growth performance, carcass, and meat traits grazing lambs. Meat Sci 2011;88:404-8.

19. Matthews JO, Southern LL, Fernandez JM, et al. Effect of chromium picolinate and chromium propionate on glucose and insulin kinetics of growing barrows and on growth and carcass traits of growing-finishing barrows. J Anim Sci 2001; 79:2172-8.

20.Zhang Q, Sun X, Xiao X, et al. Dietary chromium restriction of pregnant mice changes the methylation status of hepatic genes involved with insulin signaling in adult male offspring. PLoS One 2017;12:e0169889.

21.Mertz W, Schwarz K. Relation of glucose tolerance factor to 
impaired intravenous glucose tolerance of rats on stock diets. Am J Physiol 1959;196:614-8.

22.Lindemann MD, Wood CM, Harper AF, Kornegay ET, Anderson RA. Dietary chromium picolinate additions improve gain:feed and carcass characteristics in growing-finishing pigs and increase litter size in reproducing sows. J Anim Sci 1995; 73:457-65.

23. Freund $\mathrm{H}$, Atamian S, Fischer JE. Chromium deficiency during total parenteral nutrition. JAMA 1979;241:496-8.

24. Jeejeebhoy KN, Chu RC, Marliss EB, Greenberg GR, BruceRobertson A. Chromium deficiency, glucose intolerance, and neuropathy reversed by chromium supplementation, in a patient receiving long-term total parenteral nutrition. Am J Clin Nutr 1977;30:531-8.

25. Paiva AN, Lima JG, Medeiros AC, et al. Beneficial effects of oral chromium picolinate supplementation on glycemic control in patients with type 2 diabetes: A randomized clinical study. J Trace Elem Med Biol 2015;32:66-72.

26. Feng W, Zhao T, Mao G, et al. Type 2 diabetic rats on diet supplemented with chromium malate show improved glycometabolism, glycometabolism-related enzyme levels and lipid metabolism. PLoS One 2015;10:e0125952.

27. National Research Council. Nutrient requirements of poultry: Ninth Revised Edition. Washington, DC, USA: The National Academies Press; 1994.

28. Padmavathi IJ, Rao KR, Venu L, et al. Chronic maternal dietary chromium restriction modulates visceral adiposity: probable underlying mechanisms. Diabetes 2010;59:98-104.

29. Huang S, Peng W, Jiang X, et al. The effect of chromium picolinate supplementation on the pancreas and macroangiopathy in type II diabetes mellitus rats. J Diabetes Res 2014;2014: 717219.

30.Sahin K, Tuzcu M, Orhan C, et al. Anti-diabetic activity of chromium picolinate and biotin in rats with type 2 diabetes induced by high-fat diet and streptozotocin. Br J Nutr 2013; 110:197-205.

31.Li F, Wu X, Zhao T, et al. Anti-diabetic properties of chromium citrate complex in alloxan-induced diabetic rats. J Trace Elem
Med Biol 2011;25:218-24.

32. Anderson RA, Polansky MM, Bryden NA, Bhathena SJ, Canary JJ. Effects of supplemental chromium on patients with symptoms of reactive hypoglycemia. Metabolism 1987;36:351-5.

33.Zhang H, Dong B, Zhang M, Yang J. Effect of chromium picolinate supplementation on growth performance and meat characteristics of swine. Biol Trace Elem Res 2011;141:159-69.

34. Butterwith SC. Contribution of lipoprotein lipase activity to the differential growth of three adipose tissue depots in young broiler chickens. Br Poult Sci 1989;30:927-33.

35. Becker WA, Spencer JV, Mirosh LW, Verstrate JA. Prediction of Fat and fat free live weight in broiler chickens using backskin fat, abdominal fat, and live body weight. Poult Sci 1979;58: 835-42.

36. Thomas VG, Mainguy SK, Prevett JP. Predicting Fat content of geese from abdominal fat weight. J Wildl Manage 1983;47: 1115-9.

37.Smith S, Witkowski A, Joshi AK. Structural and functional organization of the animal fatty acid synthase. Prog Lipid Res 2003;42:289-317.

38. Jjiri D, Ishitani K, El-Deep MM, et al. Single injection of clenbuterol into newly hatched chicks decreases abdominal fat pad weight in growing broiler chickens. Anim Sci J 2016;87: 1298-303.

39. Bengtsson C, Blaho S, Saitton DB, et al. Design of small molecule inhibitors of acetyl-CoA carboxylase 1 and 2 showing reduction of hepatic malonyl-CoA levels in vivo in obese Zucker rats. Bioorg Med Chem 2011;19:3039-53.

40. Oh W, Abu-Elheiga L, Kordari P, et al. Glucose and fat metabolism in adipose tissue of acetyl-CoA carboxylase 2 knockout mice. Proc Natl Acad Sci USA 2005;102:1384-9.

41.Haemmerle G, Zimmermann R, Zechner R. Letting lipids go: hormone-sensitive lipase. Curr Opin Lipidol 2003;14:289-97.

42. Faulconnier Y, Bonnet M, Bocquier F, Leroux C, Chilliard Y. Effects of photoperiod and feeding level on adipose tissue and muscle lipoprotein lipase activity and mRNA level in dry nonpregnant sheep. Br J Nutr 2001;85:299-306. 